\title{
Participation Motivation for Extracurricular Activities: Study on Primary School Students
}

\author{
Zeycan Acar ${ }^{1}$, Nevin Gündüz,"* \\ ${ }^{1}$ Cemil Yildırım Middle School, Turkey \\ ${ }^{2}$ Department of Physical Education and Sport, Faculty of Sports Science, Ankara University, Turkey
}

Copyright $\mathrm{O} 2017$ by authors, all rights reserved. Authors agree that this article remains permanently open access under the terms of the Creative Commons Attribution License 4.0 International License

\begin{abstract}
The aim of this study is to analyse the participation motivation for extracurricular activities; study on primary school students. It also analysed whether such factors as age and sex change on the basis of their participation motivation. The population of the study is composed of 797students in primary school and, the sample is composed of 513 students. Students are participating in the extracurricular activities were included in an activity each month. Implementations continued for seven months. The activities were implemented, "Participation Motivation Scale", as a data collection tool, was applied to the students. As a result, it was determined that male and female students attending to the activities deemed "skill development" as the most important factor. There was statistically significant difference between female and male students such sub-dimensions as "fun", "success/status" and "movement/being active" in the study. The positive impacts of participation will, enthusiasm and excitements and also the students' physical, psychological and social developments were observed.
\end{abstract}

Keywords Extracurricular Activity, Student, Sport Participation Motivation

\section{Introduction}

The movement area of children is quite limited at the present time. Along with the developing technology and evolving times, expectations from children have increased and have come to the fore in the lives of children. In this regard, physical education lessons including many educative games have become obligatory for the development and education of children (Ha et.al. [14])

Extracurricular activities include any kind of activities like sports, music, painting, theatre, literature which are outside of the scope of lessons predetermined in the curriculum and are compulsory for the students. Students participate in these extracurricular activities upon their own consent and preference (Karaküçük \& Yetim, [16]). In other words, extracurricular exercises are closely related with the curricular activities in order to evaluate the leisure time of students, to provide students the opportunity of realizing themselves and to ensure development of their characteristics and skills and these activities, namely performance, chorus, orchestra, sports competitions, are implemented under the guidance and control of teachers (Selçuk [29]).

As per the point A in Article 6 of the Regulation on Primary Education- Secondary Education Institutions Sports Events in the Journal of Communiques of the Ministry of National Education (MEB [23]) it is necessary education in line with the purposes of physical education and sports only by means of physical education lessons. Therefore, importance is attached to the extracurricular activities and these activities are planned and implemented in a way to offer the opportunity of participation for everybody.

Pehlivan \& Selçuk [27] stated that the schools remain incapable to cultivate the desired behaviours for the children due to the excessive course load, crowded classes, lack of double shift schooling, material, equipment, atelier, laboratory, fields and halls, increase in knowledge, insufficiency of academic programs and determination of individual differences. Therefore, Pehlivan \& Selçuk [27] stated that out of school time should be included in education and training. Ekici et al [9] indicated that extracurricular activities are carried out in line with the general objectives of education and is a part of education and, they described extracurricular activities as events which are oriented to the interest and needs of students and are implemented according to a plan and program in order to improve students' personality under the light of the knowledge and guidance of school administration.

Participation in extracurricular activities substantially contributes to a healthy and active life of a child. Today where physical inactivity and obesity are common; encouraging children to sports, making children like sports and getting children to adopt a lifelong sports habit gain importance in order to raise a healthy generation. Especially 
for the primary and secondary school students who go through the most energetic and kinetic period of their life, in-school and extracurricular sportive events are primary in order to protect them from bad habits, improve their skills and abilities, to spend their leisure time worth fully, to use their energy in a positive way and to relieve their stress. According to the researches, participation in extracurricular activities for adolescents plays significant role in positive improvement in terms of self-perception, self-confidence, mental health and lifelong sports habit.

Due to the fact that extracurricular activities are an inseparable part of education, participation in these activities have been made compulsory in many countries in order to increase the quality in education. For instance, in Japan, moral education is delivered mainly along with sports and cultural activities. In Malesia, extracurricular activities are compulsory at all the educational grades. In China, physical education and fine arts courses are delivered as a means of improvement of morality (Köse [21]) Similarly, national and international documents are used as guides in order to encourage the youth in schools to do physical activities. Schools provide students opportunities for being physically active during lunch breaks (Torsheim et.al. [32])

Programmed extracurricular activities are of particular importance for the development of individuals as much as the curricular activities (Arabacı \& Akgül [2]) and these extracurricular activities offer opportunities to the students (Kanters et.al. [15]). Exercises that can also be called as extracurricular activity are a part and continuation of physical education lessons. Students can reiterate what they have learned in the lessons (Selçuk [29]).

Participation in extracurricular sports activities in schools has important contribution to live a healthy and active life for children (Ha et.al. [14]). Researches demonsrate that participation in extracurricular activities play important role for the positive development of self-perception, self-confidence, physchological health and adopting lifelong sports habit in adolescents participating in extracurricular activities (Daley et.al.[8]). Most of the young people at the age of 6-17 don't make daily physical activity at medium and high volume; despite the well know benefits of regular physical activity and suggestion of United States Department of Health and Human Service. According to the results of the conducted national study, $42 \%$ of children at the age range of 6-11 and $15.6 \%$ of the children at the age range of $12-19$ stated that they don't do physical exercise for 60 minutes and also they stated that there are significant inequalities in participation in sports in terms of sex and age (Kanters et.al. [15]).

For that reason, children's' participation in sports gains still more importance especially in this day and age. So, the concept of participation motivation has been determined as a concept which is required to be researched and examined within the scope of sports of the young. It is difficult to find an exact correspondence to the term of "motive" in Turkish; however it can be described as "impulse" or mobilizer and it is possible to find several descriptions of motivation in the literature. Motivation can be described as an explanation of an intrinsic characteristic, and extrinsic effect, a conclusion or behaviours (Weinberg \& Gould, [33]).

On the other hand, the term of sport participation is traditionally used in exercise psychology as attracting the individuals to the physical activity (Markland \& Inledew [22]). Many studies (Gill et.al. [12]; Gould et.al. [13]; Klint Weis [18]; Oyar et.al. [26]) were basically conducted in order to describe the reasons that guide individuals to participate in sports and physical activities and to categorize these reasons.

Koivula [20] indicated that sport participation motivations and reasons differentiate among individuals, while Weinberg \& Gould [33] stated that, more than one reason such as losing weight, feeling good and etc., may be effective in individuals' sport participation and, common motivation reasons (skill development, fun, being healthy) and personal reasons (parental pressure, the desire to do something) can predominate. Moreover, they highlighted that motivation can differ depending on age, sex and cultural differences. Gill et al. [12] developed Participation Motivation Questionnaire in order to determine the reasons of young people's participation and evaluated the participation reasons under 8 sub-dimensions namely; skill development, team membership/spirit, fun, friendship, success/status, physical fitness and other reasons (Oyar et.al. [26])

Participation motives of individuals differ considerably. This difference can arise not only in the reasons themselves but also in the strength and importance of the reasons. If a participation experience is perceived as purposeful, the person is much motivated to participate in activities related to the mentioned experience. Therefore, it can be stated that sport participation motivations and reasons differ from person to person. The reason of the number of conducted studies on children's' participation in sport can result from the fact that physical activity, sport and game occupy a considerable part of the children's' lives.

In accordance with this knowledge, the purpose of this study is to analyse the participation motivation for extracurricular activities; study on primary school students and to determine the impacts of such factors as age and sex on their participation motivations. Regarding this purpose, responses to the following questions were seeked:

1. What are the most important reasons in students' motivation in participating in physical education extracurricular activities?

2. Is the factor of age important in students' motivation in participating in physical education extracurricular activities?

3. Is there any difference between the sexes in students' motivation in participating in physical education extracurricular activities?

\section{Method}

This is a practical study and scanning method was used in this study. 


\subsection{Research Group}

This study was conducted to 513 students who are voluntarily participating in extracurricular activities out of 797 students attending to the $5^{\text {th }}, 6^{\text {th }}, 7^{\text {th }}$ and $8^{\text {th }}$ grades in Ankara Gölbaşı Atatürk Primary School in 2011-2012 academic years. 184 students who did not attend the extracurricular activities did so because of health problems and because they voluntarily did not want to participate.

\subsection{Procedure}

In this study, the students participating in extracurricular activities were made to participate in one exercise each month and in total seven exercises. These exercises were; cross competitions, dodge ball, discover your skill I, discover your skill II, we make the most baskets, shoot the ball in the middle and volleyball tournament. These practices continued for seven months in total starting from November and ending in June. These activities, included in the physical education curriculum such as running, target hit, ball control, team play, accurate hoop shots, rhythmic (with music) gymnastics, skip (rope) and step; besides being upskill for the students, are individual and group activities that enable the physical education programs gain achievements. In this practice, students participated in one or more activities they wanted to from the total of seven mentioned exercises.

The relevant event rules were practically taught to the students at all grades separately within the course hours of physical education lesson. Afterwards, these rules were implemented for the students who were participating in extracurricular activities. At the end of four weeks, tournaments were organized among the grades for 2-3 hours out of the course hours. The volunteer students among those not participating in the competitions are appointed as referee, equipment protector and security. Feedbacks received from the students were taken into consideration in determination of the events and games. "Participation Motivation Scale "was implemented to the student who participated in the extracurricular practices (events). In addition, it was explained to the students by the physical education teacher prior to the fulfilment of the questionnaire that only students with licences and who are participating in the competitions and tournaments should fill the "Sport Branch" section in the questionnaire.

\subsection{Data Collection Tool}

The data collection tool which was used in this study is "Participation Motivation Scale" that was developed by Gill, Gross and Huddleston in 1983 which is composed of 30 items and 8 sub dimensions: Skill Development, Team Membership/Spirit, Fun, Friendship, Success/Status, Energy Consume, Physical Fitness and Other Reasons [12]. The reasons of participation in sport was evaluated by means of 3 point Likert Scale as "Very Important (1), "Moderately Important" (2) and "Not Important" (3). Because the items included in the "Participation Motivation Scale" were evaluated between the values of 1 (Very Important) and 3 (Not Important), the lower values show that the item is more important. The Scale was translated to Turkish by Ölçek, Çelebi and the reliability co-efficient obtained from the whole scale was found as .91 (Oyar et.al. [26]). The reliability validity examination on the scale was made by Oyar, Aşçı, Çelebi and Mülazımoğlu (Oyar et.al. [26]) for summer sport school and ub-dimensions were determined. The Croanbach alpha internal consistency coefficient for the sub dimensions was found between .61 (Skill Development) and .78 (Success/Status). The internal consistency was calculated as .86 for the whole scale (Bayar [5]). In this study, Turkish form which was developed by Çelebi and used by Oyar et al. [26] will be used.

\subsection{Data Analysis}

The data obtained in the study was calculated via SPSS package program. First, descriptive statistics for the variables and sub dimensions were calculated in the study. The obtained data was explained through frequencies and percentages. In order to test the differences in students' motivation in terms of sex and age, t-test and one-way anova were used. In the comparison, $p<0,05$ level was taken as basis.

\section{Results}

In this study, the findings relating to the examination of participation motivations of primary school students in extracurricular activities are presented below. 
Table 1. Demographic Characteristics of the Students Participating in Events

\begin{tabular}{|c|c|c|c|}
\hline Variables & & Frequency & Percentage \\
\hline \multirow{2}{*}{ Sex } & Female & 264 & 51,5 \\
\cline { 2 - 4 } & Male & 249 & 48,5 \\
\hline Total & & 513 & 100.0 \\
\hline Age & 10 & 6 & 1,2 \\
\hline & 11 & 96 & 18,7 \\
\hline & 12 & 133 & 25,9 \\
\hline & 13 & 136 & 26,5 \\
\hline & 14 & 125 & 24,4 \\
\hline & 15 & $\mathbf{5 1 3}$ & 3,3 \\
\hline
\end{tabular}

Table 2. Distribution of Events by Months and Distribution of Participative Children by Sex

\begin{tabular}{|c|c|c|c|c|}
\hline Activities & Month & Sex & $\mathrm{N}$ & Total \\
\hline \multirow{2}{*}{ Cross } & \multirow{2}{*}{ November } & Female & 58 & \multirow{2}{*}{112} \\
\hline & & Male & 54 & \\
\hline \multirow{2}{*}{ Dodge ball } & \multirow{2}{*}{ December } & Female & 190 & \multirow{2}{*}{388} \\
\hline & & Male & 198 & \\
\hline \multirow{2}{*}{ Discover your skill I } & \multirow{2}{*}{ January } & Female & 53 & \multirow{2}{*}{92} \\
\hline & & Male & 39 & \\
\hline \multirow{2}{*}{ Discover your skill II } & \multirow{2}{*}{ February } & Female & 59 & \multirow{2}{*}{80} \\
\hline & & Male & 21 & \\
\hline \multirow{2}{*}{ We make the most baskets } & \multirow{2}{*}{ March } & Female & 113 & \multirow{2}{*}{237} \\
\hline & & Male & 124 & \\
\hline \multirow{2}{*}{ Shoot the ball in the middle } & \multirow{2}{*}{ April } & Female & 118 & \multirow{2}{*}{236} \\
\hline & & Male & 118 & \\
\hline \multirow{2}{*}{ Volleyball tournament } & \multirow{2}{*}{ May } & Female & 162 & \multirow{2}{*}{220} \\
\hline & & Male & 58 & \\
\hline
\end{tabular}

Table 3. Distribution of Students Keeping in Training and Not Keeping in Training

\begin{tabular}{|c|c|c|c|c|}
\hline \multirow{2}{*}{ Sex } & \multicolumn{2}{|c|}{ Students Keeping in Training } & \multicolumn{2}{c|}{ Students Not Keeping in Training } \\
\cline { 2 - 5 } & $\mathrm{F}$ & $\%$ & $\mathrm{~F}$ & $\%$ \\
\hline Female & 11 & 4,17 & 253 & 95,83 \\
\hline Male & 26 & 10,44 & 223 & 89,56 \\
\hline Total & 37 & 7,2 & 476 & 92,8 \\
\hline
\end{tabular}

In the study, the branches in the distribution of students doing sports by branches are football, volleyball, taekwondo, basketball, swimming and karate. In this distribution, the number of female students doing sports regularly is 11 (4.7\%) while this number is $26(10.44 \%)$ for male students.

Table 4. Descriptive Statistics of the Scores of the Study Group in Sub Dimensions in the Participation Motivation Scale

\begin{tabular}{|c|c|c|c|c|}
\hline Sub-dimensions & N & $\bar{X}$ & SS & $\bar{X}$ \\
\hline Friendship (3 Items) & 513 & 4,75 & 0,066 & 1,583 \\
\hline Success/Status (5 Items) & 513 & 7,26 & 1,813 & 1,452 \\
\hline Skill development (4 Items) & 513 & 4,96 & 1,019 & $\mathbf{1 , 2 4 0}$ \\
\hline Fun (4 Items) & 513 & 5,89 & 1,359 & 1,473 \\
\hline Physical Fitness/ Energy Consuming (5 Items) & 513 & 7,45 & 1,788 & 1,490 \\
\hline Movement/ Being Active (2 Items) & 513 & 2,62 & 1,148 & $\mathbf{1 , 2 9 5}$ \\
\hline Team Membership/ Team Spirit (4 Items) & 513 & 5,08 & 1,332 & $\mathbf{1 , 2 7 0}$ \\
\hline Competition (3 Items) & 513 & 4,22 & 1,320 & 1,406 \\
\hline
\end{tabular}


In the study, the most important factors determined by the students in the participation motivation scale are skill development $(\overline{\mathbf{X}}=1,240+1.019)$, team membership/spirit $(\overline{\mathbf{X}}=1.270+1,332)$ and being active $(\overline{\mathbf{X}}=1.295+1,148)$. The most unimportant factor is friendship $(\overline{\mathbf{X}}=1.583+0.066)$.

Table 5. The Results of the Comparison of the Scores Obtained by Students in the Participation Motivation Scale with Age (Variance Analysis)

\begin{tabular}{|c|c|c|c|c|c|c|c|}
\hline Sub-dimensions & Age & $\mathrm{n}$ & $\overline{\mathrm{X}}$ & SS & $\mathrm{SD}$ & $\mathrm{F}$ & $\mathrm{P}$ \\
\hline \multirow{6}{*}{ Friendship } & 10 & 6 & 4,67 & 1,506 & 0,615 & \multirow{6}{*}{1,215} & \multirow{6}{*}{0,456} \\
\hline & 11 & 96 & 4,59 & 1,587 & 0,162 & & \\
\hline & 12 & 133 & 4,70 & 1,365 & 0,118 & & \\
\hline & 13 & 136 & 4,57 & 1,489 & 0,128 & & \\
\hline & 14 & 125 & 5,08 & 1,569 & 0,140 & & \\
\hline & 15 & 17 & 5,18 & 0,951 & 0,231 & & \\
\hline \multirow{6}{*}{ Success } & 10 & 6 & 7,17 & 1,329 & 0,543 & \multirow{6}{*}{1,914} & \multirow{6}{*}{0,816} \\
\hline & 11 & 96 & 7,35 & 1,692 & 0,173 & & \\
\hline & 12 & 133 & 7,41 & 1,871 & 0,162 & & \\
\hline & 13 & 136 & 6,85 & 1,711 & 0,147 & & \\
\hline & 14 & 125 & 7,28 & 1,808 & 0,162 & & \\
\hline & 15 & 17 & 8,59 & 2,320 & 0,563 & & \\
\hline \multirow{6}{*}{ Skill Development } & 10 & 6 & 3,17 & 0,408 & 0,167 & \multirow{6}{*}{0,635} & \multirow{6}{*}{0,418} \\
\hline & 11 & 96 & 3,61 & 1,009 & 0,103 & & \\
\hline & 12 & 133 & 3,54 & 0,875 & 0,076 & & \\
\hline & 13 & 136 & 3,57 & 0,932 & 0,080 & & \\
\hline & 14 & 125 & 3,94 & 1,210 & 0,108 & & \\
\hline & 15 & 17 & 3,88 & 1,111 & 0,270 & & \\
\hline \multirow{6}{*}{ Fun } & 10 & 6 & 6,50 & 1,517 & 0,619 & \multirow{6}{*}{1,823} & \multirow{6}{*}{0,723} \\
\hline & 11 & 96 & 5,82 & 1,436 & 0,147 & & \\
\hline & 12 & 133 & 6,11 & 1,418 & 0,123 & & \\
\hline & 13 & 136 & 5,74 & 1,229 & 0,105 & & \\
\hline & 14 & 125 & 5,86 & 1,334 & 0,119 & & \\
\hline & 15 & 17 & 5,71 & 1,490 & 0,361 & & \\
\hline \multirow{6}{*}{$\begin{array}{l}\text { Physical Fitness/ Energy } \\
\text { Consuming }\end{array}$} & 10 & 6 & 6,67 & 1,366 & 0,558 & \multirow{6}{*}{1,736} & \multirow{6}{*}{0,694} \\
\hline & 11 & 96 & 7,11 & 1,548 & 0,158 & & \\
\hline & 12 & 133 & 7,50 & 1,901 & 0,165 & & \\
\hline & 13 & 136 & 7,51 & 1,764 & 0,151 & & \\
\hline & 14 & 125 & 7,68 & 1,843 & 0,165 & & \\
\hline & 15 & 17 & 6,94 & 1,886 & 0,458 & & \\
\hline \multirow{6}{*}{ Movement/ Being Active } & 10 & 6 & 3,33 & 0,516 & 0,211 & \multirow{6}{*}{0,712} & \multirow{6}{*}{0,527} \\
\hline & 11 & 96 & 3,90 & 1,090 & 0,111 & & \\
\hline & 12 & 133 & 4,05 & 1,205 & 0,105 & & \\
\hline & 13 & 136 & 3,81 & 1,099 & 0,094 & & \\
\hline & 14 & 125 & 4,08 & 1,168 & 0,104 & & \\
\hline & 15 & 17 & 4,24 & 1,300 & 0,315 & & \\
\hline \multirow{6}{*}{ Team Membership } & 10 & 6 & 4,67 & 0,816 & 0,333 & \multirow{6}{*}{0,927} & \multirow{6}{*}{0,319} \\
\hline & 11 & 96 & 4,88 & 1,113 & 0,119 & & \\
\hline & 12 & 133 & 8,21 & 2,030 & 0,176 & & \\
\hline & 13 & 136 & 4,93 & 1,266 & 0,109 & & \\
\hline & 14 & 125 & 5,20 & 1,276 & 0,114 & & \\
\hline & 15 & 17 & 5,65 & 1,498 & 0,363 & & \\
\hline & 10 & 6 & 4,00 & 1,265 & 0,516 & & \\
\hline & 11 & 96 & 4,44 & 1,457 & 0,149 & & \\
\hline & 12 & 133 & 4,30 & 1,376 & 0,119 & 0710 & \\
\hline Competition & 13 & 136 & 4,10 & 1,229 & 0,105 & 0,719 & 0,428 \\
\hline & 14 & 125 & 4,12 & 1,267 & 0,113 & & \\
\hline & 15 & 17 & 4,12 & 1,111 & 0,270 & & \\
\hline
\end{tabular}

As a result of the comparison of the scores gained by the students under the sub dimension of sport participation motivation by age, there was not a statistically significant importance $(\mathrm{P}>0,05)$. 
Table 6. Results of Comparison of Sub Dimensions of Participation Motivation According to the Variable of Sex (t-test)

\begin{tabular}{|c|c|c|c|c|c|c|}
\hline Sub-dimensions & Sex & $\mathrm{N}$ & $\overline{\mathrm{X}}$ & SS & $\mathrm{T}$ & $\mathrm{P}$ \\
\hline \multirow{2}{*}{ Friendship } & Male & 249 & 4,97 & 1,575 & \multirow{2}{*}{1.523} & \multirow{2}{*}{0,21} \\
\hline & Female & 264 & 4,53 & 1,365 & & \\
\hline \multirow{2}{*}{ Success/Status } & Male & 249 & 7,29 & 1,889 & \multirow{2}{*}{2.879} & \multirow{2}{*}{$0,01 *$} \\
\hline & Female & 264 & 7,24 & 1,733 & & \\
\hline \multirow{2}{*}{ Skill development } & Male & 249 & 3,69 & 1,025 & \multirow{2}{*}{1.015} & \multirow{2}{*}{0,98} \\
\hline & Female & 264 & 3,64 & 1,014 & & \\
\hline \multirow{2}{*}{ Fun } & Male & 249 & 5,93 & 1,452 & \multirow{2}{*}{2.231} & \multirow{2}{*}{$\mathbf{0 , 0 3 *}$} \\
\hline & Female & 264 & 5,85 & 1,254 & & \\
\hline \multirow{2}{*}{ Physical Fitness/ Energy Consume } & Male & 249 & 7,57 & 1,753 & \multirow{2}{*}{3.457} & \multirow{2}{*}{0,77} \\
\hline & Female & 264 & 7,32 & 1,818 & & \\
\hline \multirow{2}{*}{ Movement/Being Active } & Male & 249 & 3,95 & 1,107 & \multirow{2}{*}{1.216} & \multirow{2}{*}{$0,02 *$} \\
\hline & Female & 264 & 3,97 & 1,193 & & \\
\hline \multirow{2}{*}{ Team Membership / Team Spirit } & Male & 249 & 5,21 & 1,402 & \multirow{2}{*}{2.014} & \multirow{2}{*}{0,58} \\
\hline & Female & 264 & 4,95 & 1,242 & & \\
\hline Competition & Male & 249 & 4,38 & 1,368 & 1.417 & 0,84 \\
\hline
\end{tabular}

$* \mathrm{p}<0,05$

Table 7. Average and Standard Aviation of the Scores Gained by the Students from the Participation Motivation Scale According to Sex

\begin{tabular}{|c|c|c|c|c|}
\hline \multirow{2}{*}{ MOTIVES OF SPORTS PARTICIPATION } & \multicolumn{2}{|c|}{$\begin{array}{c}\text { FEMALE } \\
\mathrm{N}=264\end{array}$} & \multicolumn{2}{|c|}{$\begin{array}{l}\text { MALE } \\
\mathrm{N}=249\end{array}$} \\
\hline & $\bar{X}$ & SS & $\bar{X}$ & SS \\
\hline $\begin{array}{c}\text { Friendship } \\
\text { I want to be with my friends } \\
\text { My family and friends want me to play } \\
\text { I want to meet new friends }\end{array}$ & $\begin{array}{l}1,47 \\
1,81 \\
1,68\end{array}$ & $\begin{array}{l}0,610 \\
0,794 \\
0,706\end{array}$ & $\begin{array}{l}1,33 \\
1,67 \\
1,53\end{array}$ & $\begin{array}{l}0,570 \\
0,728 \\
0,654\end{array}$ \\
\hline $\begin{array}{l}\text { Success/Status } \\
\text { I am willing to do something for the sake of the things that I am good at. } \\
\text { I like winning awards } \\
\text { I am happy when I feel that I am important } \\
\text { I want to be popular } \\
\text { I want to gain prestige and status }\end{array}$ & $\begin{array}{l}1,11 \\
1,44 \\
1,34 \\
1,98 \\
1,41\end{array}$ & $\begin{array}{l}0,341 \\
0,650 \\
0,562 \\
0,785 \\
0,616\end{array}$ & $\begin{array}{l}1,18 \\
1,44 \\
1,34 \\
1,93 \\
1,35\end{array}$ & $\begin{array}{l}0,422 \\
0,676 \\
0,582 \\
0,803 \\
0,570\end{array}$ \\
\hline $\begin{array}{c}\text { Skill Development } \\
\text { I want to develop my skills } \\
\text { I want to get new skills } \\
\text { I want to advance in my branch } \\
\text { I want to benefit from equipment and facilities }\end{array}$ & $\begin{array}{l}1,25 \\
1,17 \\
1,27 \\
1,54\end{array}$ & $\begin{array}{l}0,489 \\
0,442 \\
0,546 \\
0,702\end{array}$ & $\begin{array}{l}1,26 \\
1,22 \\
\mathbf{1 , 1 6} \\
1,39\end{array}$ & $\begin{array}{l}0,506 \\
0,503 \\
0,413 \\
0,658\end{array}$ \\
\hline $\begin{array}{c}\text { Fun } \\
\text { I like travelling } \\
\text { I like excitement } \\
\text { I like going out of home } \\
\text { I like fun }\end{array}$ & $\begin{array}{l}1,51 \\
1,33 \\
1,96 \\
\mathbf{1 , 1 4}\end{array}$ & $\begin{array}{l}0,708 \\
0,565 \\
0,757 \\
0,616\end{array}$ & $\begin{array}{l}1,59 \\
1,34 \\
1,79 \\
\mathbf{1 , 1 3}\end{array}$ & $\begin{array}{l}0,685 \\
0,561 \\
0,687 \\
0,370\end{array}$ \\
\hline $\begin{array}{l}\text { Physical Fitness/ Energy Consume } \\
\text { I want to consume my energy } \\
\text { I want to protect my form } \\
\text { I want to relieve stress } \\
\text { I like doing exercise } \\
\text { I want to be physically healthy } \\
\end{array}$ & $\begin{array}{l}2,03 \\
1,52 \\
1,58 \\
1,28 \\
1,17\end{array}$ & $\begin{array}{l}0,774 \\
0,719 \\
0,693 \\
0,489 \\
0,451\end{array}$ & $\begin{array}{l}1,78 \\
1,37 \\
1,50 \\
1,49 \\
1,18\end{array}$ & $\begin{array}{l}0,743 \\
0,610 \\
0,642 \\
0,642 \\
0,441 \\
\end{array}$ \\
\hline $\begin{array}{l}\text { Movement/ Being Active } \\
\text { I like being busy with something } \\
\text { I like movement }\end{array}$ & $\begin{array}{l}1,36 \\
1,22\end{array}$ & $\begin{array}{l}0,485 \\
0,445\end{array}$ & $\begin{array}{l}1,24 \\
1,17\end{array}$ & $\begin{array}{l}0,579 \\
0,455\end{array}$ \\
\hline $\begin{array}{c}\text { Team Membership/ Spirit } \\
\text { I like team work } \\
\text { I like team spirit } \\
\text { I like to be in a team } \\
\text { I like the leader, trainer and skipper }\end{array}$ & $\begin{array}{l}1,24 \\
1,39 \\
\mathbf{1 , 1 1} \\
1,46\end{array}$ & $\begin{array}{l}0,495 \\
0,587 \\
0,330 \\
0,663\end{array}$ & $\begin{array}{l}\mathbf{1 , 1 2} \\
1,26 \\
1,13 \\
1,44\end{array}$ & $\begin{array}{l}0,361 \\
0,552 \\
0,380 \\
0,607\end{array}$ \\
\hline $\begin{array}{c}\text { Competition } \\
\text { I like winning } \\
\text { I like rivalry } \\
\text { I like challenging }\end{array}$ & $\begin{array}{l}1,25 \\
1,34 \\
1,79\end{array}$ & $\begin{array}{l}0,491 \\
0,588 \\
0,826\end{array}$ & $\begin{array}{l}1,29 \\
1,22 \\
1,54\end{array}$ & $\begin{array}{l}0,545 \\
0,493 \\
0,718\end{array}$ \\
\hline
\end{tabular}


The results of the t-test which was applied to test the difference among the participation motivation of the students in terms of sex showed that there is a significant difference between female and male students in the sub dimensions of "fun" ( $t=2,231 ; p<0,05)$, "success/status" $(t=2.879 ; p<0,05)$ and "movement/being active" $(\mathrm{t}=1,216 ; \mathrm{p}<0,05)$. It was determined that there is not a significant difference in the sub dimensions of "competition", "team membership/spirit", "physical fitness/energy consume" and "friendship" $(p>0,05)$. On the other hand, it was identified while the sub dimensions of success/status and fun are more important for female students, movement/being active sub dimension is more important for male students.

The factors that is deemed important for participation in extracurricular activities by the female students who attended to the study are "I like doing something that I am good at", "I like being in a team" and "I like fun", respectively. The reason that female students regard as the most unimportant is "I want to be popular". On the contrary, the most important reasons for participating in extracurricular activities for male students are "I like team work", "I like fun" and "I want to be promoted in my branch", respectively. According to the results of the analysis, it was determined that both female and male students deem the factor of "I want to be popular" as the most unimportant reason for participating in extracurricular activities.

\section{Discussion}

In this study, it was determined that out of 513 total students who attended to the activities; 264 of them were female and 249 were male. Koca [19] stated that in Turkish society, boy children are encouraged to do sports by their parents in order to develop their masculinity while girl children are prevented especially from risky sports that require strength in order to protect their bodies and femininity; and therefore the rate of sports participation among girls is lower than the participation rate of boy children. In this regard, the result of the higher rate of participation among male students when compared with female students in this study supports this idea. In the study conducted by Esteban et al. [11] they determined that the participation in extracurricular activities among male students were higher when compared with the participation among female student. The study conducted by Meester et. $\mathrm{Al}$ [24] in order to examine the participation motivation in extracurricular activities, they determined significant difference in participation in terms of sex. The participation of male students was determined as $82.77 \%$ while this rate was $68.11 \%$ for female students.

When we examine the descriptive statistics of the scores for sub dimensions of "Participation Motivation Scale" in which female and male students were jointly evaluated, it was determined that the score averages obtained by the individuals differ according to the factor. Accordingly, the factors that are deemed as the most important by all the students for their participation in extracurricular activities are skill development, movement/ being active and team membership while they regarded the factor of friendship as the most unimportant one. Similarly, Arslan \& Altay [3] found in a study which was conducted in order to examine the participation motivation of male students whose average age was 13 and who were in primary school teams that the most important reasons for participation in sport were skill development and competition. They determined less important reasons as physical fitness/energy consume, success/status and fun. Similarly, Salguero et al. [28] determined in a study they conducted with Spanish swimmers with the average age of 14 that the most important factor for the swimmers is the sub dimension of skill development.

Altıntaş et al. [1] found in a study they examined the correlation between sport participation motivations and success perceptions of young football players with the average age of 14 that the football players demonstrated skill development and team membership as the most important factor for their participation motivation. On the contrary, Kiper [17] found in his study where he compared participation motivation of students in the educational institutions according to sex and age groups, he found the most important reasons when male and female students were jointly evaluated as skill development, physical fitness/energy consume, success/status and fun, respectively. He found team membership/team spirit and friendship as the reason for less participation. In the study of Kiper [17] only physical fitness/energy consume, success/status and fun factors were among the most important reasons while in this study the same factors were determined as the most unimportant reasons for male and female students' participation in extracurricular activities.

In the study conducted by Saap and Haubenstricker (1978) where they researched the reasons for sport participation of 1000 female and male students whose ages were between 11 and 18 , they found the reasons for participation as fun, skill development, physical fitness, being with friends and having new friends cited by Yilmaz [34].

Another finding obtained in this study is that although the students at different ages showed a different reason for participation within the scope of each sub dimension, there was not a significant difference among the ages. This result demonstrates similarity with some studies in the literature. For instance, Şirin et.al. [31] found in a study where the reasons of participation of female athletes whose average age was 13 was researched that there was no significant difference among age groups and so age does not affect participation motivation. On the other hand; Gould et al. [13], Brodkin and Weis [6], Daley O Gara [7] and Salguera et al. [28] have concluded in their studies that age has an influence on the motivation of participation in sports activities. This literature outcome is an important difference that distinguishes ours from the other literature studies on 
motivation for participating in sports activities by age. Another significant difference is that the age range (10-15 years old) of the study group in this study is much younger than the others in this literature. In addition, since the research group has worked in a wide range, the literature might have revealed the awareness of participation motivation by age. For example, the study group of Salguera et al.[28] consisted of an age range of 8-22; while Gould et al. [13] worked with a group at the ages of 8-19, and Brodkin and Weiss [6], on the other hand, prefered to make their study on six different age groups.

The researches conducted in this literature mainly examine the participation motivation of the young people who are regularly doing exercises. In this study, the number of the students regularly doing exercises is quite low. Most of the participant students filled the questionnaire considering their experiences on physical education lessons and extracurricular activities. While significant differences have been determined in many studies in the literature and age has been determined as an effective factor in participation motivation, in this study; significant difference was not found among ages in participation motivation of the students. The reason is may be the perspective of the participant students upon sports. In other words, the experiences and visions of both the students who are only doing exercise in physical education lessons and extracurricular activities and, those athletes who do sports in clubs regularly may have affected the result. In the literature, age based studies indicate that at early ages (8-11 years) friendship, team membership and skills development are the underlying reasons that remain in the forefront of the sub-dimension of motivation for participating in sports activities Gould et al., [13]; while with increasing age; competition, rivalry, physical fitness and developing new skills Brodkin and Weiss, [6] and Salguera et al. [28] turn out to be more significant in constituting the sub-dimensions.

The researches demonstrate that the participation motivation of male students is higher when compared with the participation motivation of female students (Meester et al. [24]). According to the results of t-test which was implemented to test the sex differences in participation motivation of the students, it was determined that there is a statistically significant difference between male and female students. It was concluded from the examination of sub dimensions in the study that female student attach more importance to success/status and fun while male students give more priority to movement/being active. In the study of Kiper [17] significant differences were found among the sub dimensions of physical fitness/energy consume, fun, friendship and team membership/team spirit and competition in terms of sex.

On the other hand, when the answers given under each sub dimension by female and male students were examined, it was determined that the most important reason for female students' participation were "I want to do something I am good at", "I like being in a team" and "I like fun". The most unimportant reason was identified as "to be popular". Male students stated "I like team work", "I like fun" and "I like to get promotion in my branch" as the most important reason for their participation. Also, the most unimportant reason for their participation was determined as "to be popular", as it is for female students.

Barber et al. [4] concluded from their study in which they examined the effects of parents and trainers in young athletes' participation motivation that male athletes in the age group of 9-14 attach more importance to success and status than female athletes. The result obtained by Barber et al. supports the findings of this study. On the contrary, Erdoğdu et al. [10] stated in their study where they researched the participation motivation of secondary education students who are included in the school teams and are from different branches that the most important reason for female students' participation is team membership while this reason is skill development for male students. Friendship was considered as the most unimportant reason by both of the groups. The result also demonstrated that the sub dimension of fun is among the important reasons for female students. In the study of Zahariadis et al. [35] where they measured the sport motivation of primary education students with the age average of 13 , it was found that male students are more affected from the intrinsic motivation factors (physical fitness, skill development and competition)compared to the female students. Salguero et al. [28] found in their study they conducted with 428 young Spanish swimmers that females give priority to fun and friendship sub dimensions rather than success and status, contrary to the males. Therefore, the findings on the difference between sexes in terms of participation motivation obtained from the mentioned studies are in parallel with the findings of this study.

Sirard et al. [30] concluded in their study where they examined the motivational factors of secondary education students' participation is sports that male students prefer competitive sports while female students mainly participate in sports due to the social opportunities that come with the sports. Yilmaz [34] in their study on the reasons for participation of children, found significant differences in sports motivation of the athletes in the age range of 8-14 depending on sex and type of the sport. It was determined that team spirit and being active sub dimensions are higher in athletes participating in team sports than in those participating in individual sports. Moreover, Y1lmaz [34] determined that such sub factors as team spirit, physical fitness, fun, friendship and competition are much important for male athletes than it is for female athletes. Nielsen \& Pfister [25] stated in a case study based on sex in physical education that most of the male students like doing sports and have tendency in doing physical activity and sports while many of the female students participate in sports in order to have better body shape.

In this research, the positive impacts of participation in events on the students' will, enthusiasm and excitements and the positive impacts of participation in extracurricular 
physical activities on the students' physical, psychological and social developments were observed. The students who are attending to the events spent their time by playing games and entertaining in the school gardens under the supervision of their physical education teachers instead of spending their time in the streets, at home, on the computer without any movement. Moreover, the physical education teachers identified that students with problems of adaptation also participated in these events and therefore they easily adapted to the school and their absence rate decreased. In this regard, it can be ensured that students adapt to and like the school by explaining to them that school is not a place where only courses are delivered and exams are applied but it is a place where enjoyful games are played and events are organised. As a conclusion, today where physical inactivity and obesity are common; encouraging children to sports, making children like sports and getting children adopt a lifelong sports habit is getting more important in order to raise a healthy generation. In this regard, the most important responsibility should be covered by primarily parents, physical education teachers, trainers and managers. However, while undertaking this responsibility, the factors that refer children to sports should be determined and the programs should be prepared in line with the needs and age groups of the children. While preparing exercises programs, it should be taken into consideration that each child is affected from separate reason for motivation. Additionally, it should be remembered while preparing sports program that sex difference affects participation motivation. Moreover; sports programs in accordance with the needs and expectations of children and sport facilities and sport opportunities can be provided thanks to this study and alike studies to be conducted in the future. The required importance should be attached to the extracurricular activities in the educational institutions and these activities should be planned and implemented in line with their purposes. Extracurricular activities should not be only prepared for the training of school teams but they should be planned in a way to reach students who could not seize the opportunity of manifesting themselves and in a way to make children like sports. In addition, not only the teachers should be regarded as responsible for the preparation, organization and implementation of extracurricular activities but also the coordination among the school managers, teachers, parents and environment should be properly ensured. Whatever the conditions are, it is possible to have the student to do activities that will make him/her active by active and creative physical education teachers. It is important that teacher candidates are trained in a way to have this qualification.

\section{REFERENCES}

[1] Altıntaş, A. (2010). Sporcuların Hedef Yönelimleri, Algılanan Güdüsel İklimleri ve Algılanan Fiziksel Yeterliklerinin
Cinsiyete ve Deneyim Düzeyine Göre Karşılaştırılması. Masters' Thesis, Ankara University, Institute of Health Sciences.

[2] Arabac1, İ.B. \& Akgül, D. (2012). İlköğretim Kurumu Öğrencilerinin Sosyal Kulüp Etkinlikleri Konusundaki Görüşleri: Bitlis Province Example. e -Journal of New World Sciences Academy, 7:1, Article number: 1C0515.

[3] Aslan,Y. \& Altay, F.,(2009). İlköğretim Okul Takımlarındaki Erkek Öğrencilerin Spora Katılım Güdülerinin İncelenmesi. Celal Bayar University, Jourbal of Physical Education and Sports Sciences, 4: 2, 59-66.

[4] Barber, H., Sukhi, H. \& White, S.A. (1999). The influence of parent-coaches on participant motivation and competitive anxiety in youth sport participants. Journal of Sport Behavior, 22: 2,162 .

[5] Bayar, P. (2010). Türkiye'de Kullanılan Egzersiz ve Spor Psikoloji Testleri. Gündüz ducation and Publishing .p. 61-62.

[6] Brodkin, P. \& Weis, M.R. (1990). Developmental differences in motivation for participating in competitive swimming. Journal of Sport and Exercise Psychology, 12, 248-263.

[7] Daley, A J. \& Leahy,J. (2003). Self Perceptions and Participation in Extracurricular Physical Activities. Physical Educator Publisher, 60: 2.

[8] Daley, A., \& O'gara, A. (1998). Age, Gender and Motivation for Participation in Extracurricular Physical Activities in Secondary School Adolescents. European Phsical Education Review,4: 1, 47- 53.

[9] Ekici, S., Bayrakdar, A. \& Uğur, O. (2009). Ortaöğretim Kurumlarındaki Yöneticilerin ve Öğrencilerin Ders Dış1 Etkinliklere Bakış Açılarının İncelenmesi. International Journal of Human Sciences, $6:$ 1, 430- 444.

[10] Erdoğdu, M., Şirin, E. F., İnce, A. \& Öçalan, M. (2010). Farklı Branşlarda Okul Takımlarında Yer Alan Orta Öğretim Öğrencilerinin Spora Katılım Motivasyonlarının İncelenmesi. 11 th International Sports Sciences Congress, Antalya, 633-635.

[11] Esteban, I., Martinez, S.G, Tejerogonzalez, C.M., Castillo, R., Lanza-Saiz, R., Vicenterodriguez, G., Marcos, A. \& Gomez, D.M., (2014), Characteristics of extracurricular physical activity and cognitive performance in adolescents. The Avena study, Journal of Sports Sciences, Volume 32, Issue 17.

[12] Gill, D.L., Gross, J.B. \& Huddleston, S. (1983). Participation motivation in youth sport. International Journal of Sport Psychology, 14, 1-14.

[13] Gould, D., Feltz, D., \& Weiss, M. (1985). Motives for participating in competitive youth svvimming. International Journal of Sport Psychology, 16: 2, 126-140.

[14] Ha, A.S., Johns, D. P. \& Shui, E. W. (2003). Students' Perspective in the Desing and Implementation of the Physical Education Curriculum. Physical Education Publisher, 60.

[15] Kanters, M. A., Edwards, M. B., \& Floyd M. F., (2013), School Sport Participation Under Two School Policies, Comparison by Race/Ethnicity and Socioeconomics Status, Ann.Behev. Med. 45 (suppli) 5:113-121.

[16] Karaküçük, S. \& Yetim, A. (1999). Okul Yöneticilerinin Ders Dışı Etkinliklere Yaklaşımları. Gazi Journal of Physical Education and Sports Sciences, 4: 3, 51- 62. 
[17] Kiper,H., (2004). Eğitim Kurumlarında Öğrencilerin Spora Katılım Motivasyonlarının Cinsiyete Ve Yaş Guruplarına Göre Karşılaştırılması. Non-published Masters' Thesis. Ege University, Institute of Health Sciences.

[18] Klint, K. \& Weiss, M. (1987). Perceived competence and motives for participating in youth sports: A test of Harter's competence motivation theory. Journal of Sport Psychology, 9, $55-65$.

[19] Koca, C. (2006). Beden Eğitimi ve Spor Alanında Toplumsal Cinsiyet İlişkileri. Hacettepe Journal of Sports Sciences. 17: 2, 81-99.

[20] Koivula, N. (1999). Sport Participation: Differences inmotivation actual participation due to gender typing. J Sport Behav, 22: 3, 360- 80.

[21] Köse, E. (2003). İlköğretim düzeyinde ders diş1 etkiliklerin akademik başarıya ve okul kültürünü algılamaya etkisi, Doctorate Thesis, 25.

[22] Markland, D. \& Ingledew, D. K. (2007). Exercise Participation Motives, A Self Determination Theory Perspective. Intrinsic Motivation and Self Determination in Exercise and Sport. Ed.: M. Hagger, N. Chatzisarantis. Human Kinetics. 23-34.

[23] MEB. (2010). İlköğretim Kurumlar1- Ortaöğretim Kurumları Spor Yarışmaları Yönergesi. Tebliğler Dergisi. Şubat 2010/ 2629.

[24] Meester, A., Aelterman, N., Cardon, G., Bourdeaudhuij, I., Haerens, L. (2014). Extracurricular school-based sports a motivating vehicle for sportsparticipation in youth: a cross-sectional study.The International Journal of Behavioral Nutrition and Physical Activity. April 7, 2014, Vol. 11, 48

[25] Nielsen, W.N. \& Pfister, G., (2011), Gender Constructions and Negatiations in Physical Education and Society, Vol: 16, No: 5, Pp:645-664.

[26] Oyar, Z. B., Așçı, H. F., Çelebi, M. \& Mülazımoğlu, Ö. (2001). Spora katılım güdüsü ölçeğinin geçerlik ve güvenirlik çalışması. Hacettepe Journal of Sports Sciences, 12: 2, 21-23.
[27] Pehlivan, Z. \& Selçuk,T. (2005). Ders D1ş1 Spor Etkinliklerine Yönelik Öğretmen Görüşleri. (Mersin İli Örneği). 4th National Physical Education and Sports Teacher Symposium June 10-11, Bursa.

[28] Salguero, A., Gonzales, B.R., Tuero, C. \& Marquez, S. (2004) .Relationship between perceived physical abilility and sport participation motives in young competitive swimmers. Journal of Sports Medicine and Physical Fitness, 44: 3, 294-299.

[29] Selçuk, T. (2006). Ortaöğretim Öğrencilerinin Ders Dışı Okul Spor Faaliyetlerine Katılımı ve Sorunları (Mersin İli Örneği). Non-published Masters Thesis.Mersin University, Institute of Health Sciences

[30] Sirard,JR., Pfeiffer, KA. \&, Pate, RR. (2006). Motivational factors associated with sports program participation in middle school students. J Adolesc Health. Jun; 38(6):696-703

[31] Şirin, E. F., Çağlayan, H. S., Çetin, M. Ç. \& İnce, A. (2008). Spor Yapan Lise Öğrencilerinin Spora Katılım Motivasyonlarına Etki Eden Faktörlerin Belirlenmesi. Niğde University, Jourrnal of Physical Education and Sports Sciences 2: 2, 98- 110 .

[32] Torsheim, T., Sallis, J. F. \& Samdal, O. (2008). The Characteristics Of The Outdoor School Environment Associated Of Physical Avtivity. Oxford Journals, Health Education Research, 25: 2, 248- 256.

[33] Weinberg, R. \& Gould, D. (1995). Foundations of Sport and Exercise Psycology. Human Kinetics. p.: 60- 72.

[34] Yılmaz,V.(2002). Çocuk Sporlarında Katılım Motivasyonu.Cocuklar Spora Neden Katılırlar? .Athletism Journal of Sports and Science, 2: 26- 38.

[35] Zahariadis, P. N., Tsorbatzoudis, H. \& Grouios, G. (2005). The Sport Motivation Scale for Children: Preliminary Analysis In Physical Education Classes. Perceptual and Motor Skills, 101, 43-54. 